\title{
Argon laser surgery of mucous membranes papillomatosis in EEC syndrome and Goltz syndrome*
}

\author{
K.A. Pasyk and D.A. Hernandez \\ Section of Plastic and Reconstructive Surgery, Department of Surgery, University of Michigan Medical School, Ann Arbor, Michigan, \\ USA
}

Summary. This article describes successful results after argon laser surgery of verrucous and papillomatous lesions on the mucous membranes of the lips in two patients; the first with the EEC syndrome and the second with the Goltz syndrome. Our report is confirmation that laser energy, because is not cumulated in tissues, may be safely used for retreatment of these recalcitrant lesions.

Key words: Ectrodactyly-ectodermal dysplasia clefting syndrome - EEC syndrome - Focal dermal hypoplasia - Goltz syndrome - Papillomatosis of mucous membranes - Argon laser surgery

Congenital anomalies consisting of ectrodactyly (split foot and hand deformity of the "lobster-claw" type) and cleft lip and palate, were first documented by Eckoldt and Martens [8] in 1804, later by Cockayne [6] in 1936, and Walker and Clodius [43] in 1963. However, in 1970 Rudiger and colleagues [39] noted the correlation between these uncommon, apparently unrelated, abnormalities and ectodermal dysplasia (anomalies of hair, teeth, nails, nasolacrimal ducts and sweat glands), and used the term ectrodactyly-ectodermal dysplasia-cleft lip and palate syndrome (EEC-syndrome) for this rare autosomal dominant entity.

A similar complex set of congenital mesoectodermal abnormalities, known as Goltz syndrome, was described in 1962 by Goltz and colleagues [16] and called focal dermal hypoplasia. Besides various and numerous skeletal, ocular, otic and cardiac defects, the hallmark is hy-

* Presented in part at the Fifth International Congress of Laser Medicine and Surgery, Detroit, MI October, 1983

Requests for reprints: Prof. Krystyna A. Pasyk, Section of Plastic and Reconstructive Surgery, Alfred Taubman Health Care Center, Room 2130, 1500 East Medical Center Drive, Box 0340, Ann Arbor, Michigan 48109, USA poplasia of the dermis and papillomatous lesions on the lips, buccal mucosa, genitals, and perianal area in this X-linked dominant form of inheritance entity [29].

Both the EEC syndrome and the Goltz syndrome, require several surgical procedures and reconstructive surgery to correct the numerous associated anomalies.

This article presents the results of argon laser surgery of papillomatous lesions on mucous membranes in one patient with the EEC syndrome and in a second patient with the Goltz syndrome.

\section{Patient histories}

\section{Patient 1}

A 15-year-old boy with the EEC syndrome was referred to the Plastic Surgery Laser Clinic for laser treatment of the papillomatous lesions in his lips. The patient was a result of an uncomplicated pregnancy to his mother when she was 18 years old. The patient was born with split feet and deformities of the hands of the "lobster-claw" type (Figs. 1 a, b) and bilateral cleft lip and cleft palate. Various ectodermal anomalies such as hypodontia, defective nails, hypotrichosis, heat intolerance, atresia or defects of the lacrimal duct system, chronic blepharitis, and papillomatosis of the lips were noted during his first years of life. No member of his family was affected with any similar abnormalities. His mother has had multiple spontaneous abortions. Her chromosome study was normal.

The patient has undergone numerous surgical procedures involving repair of the cleft lip and palate and nasolacrimal duct obstruction as well as reconstruction of the right nasolacrimal duct with placement of a plastic tube. The patient has had multiple episodes of blepharitis, conjunctivitis and corneal ulcers.

On examination, bilateral scars on the upper lip were present as well as papillomatous lesions measuring approximately $1.5 \mathrm{~cm}$ in diameter. However, the lower lip, including its mucous membrane, was almost entirely covered by papillomas (Fig. 2a). Before argon laser surgery ${ }^{1}$ was performed, a biopsy specimen was taken from the papillomatous lesions. Histological examination revealed papillary mucosal hyperplasia with neutrophilic exocytosis. Special stains for fungi were negative (Fig. 3).

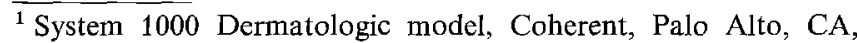
USA
} 

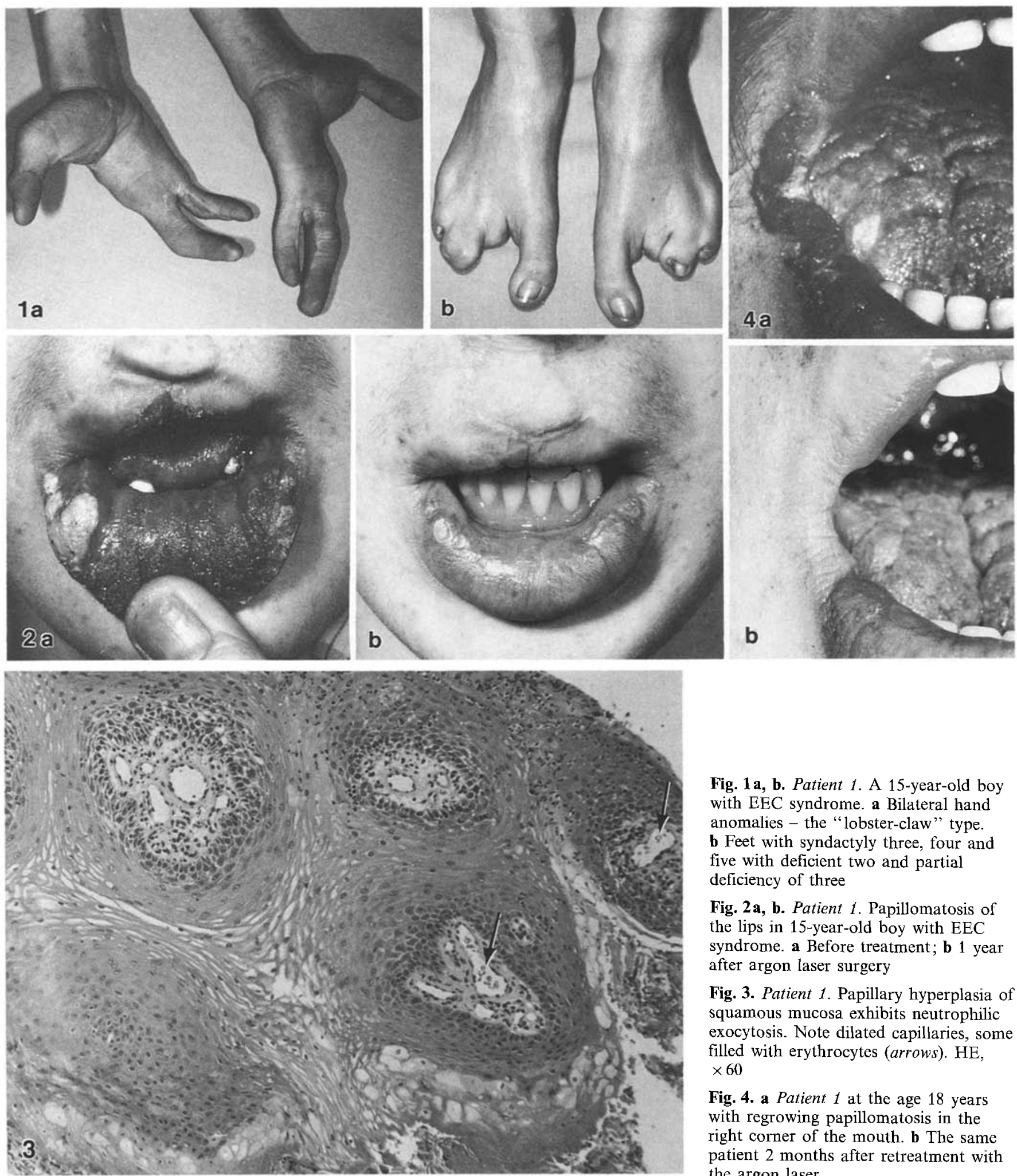

Fig. 1a, b. Patient 1. A 15-year-old boy with EEC syndrome. a Bilateral hand anomalies - the "lobster-claw" type. b Feet with syndactyly three, four and five with deficient two and partial deficiency of three

Fig. 2a, b. Patient 1. Papillomatosis of the lips in 15-year-old boy with EEC syndrome. a Before treatment; b 1 year after argon laser surgery

Fig. 3. Patient 1. Papillary hyperplasia of squamous mucosa exhibits neutrophilic exocytosis. Note dilated capillaries, some filled with erythrocytes (arrows). $\mathrm{HE}$, $\times 60$

Fig. 4. a Patient 1 at the age 18 years with regrowing papillomatosis in the right corner of the mouth. $\mathbf{b}$ The same patient 2 months after retreatment with the argon laser

After local anesthesia with $2 \%$ lidocaine without epinephrine, the argon laser test treatment was performed on the papillomatous lesions on the upper lip using a power density of $216-255 \mathrm{~W} / \mathrm{cm}^{2}$, i.e., energy fluence $43.3-50.9 \mathrm{~J} / \mathrm{cm}^{2}$ (exposure time $0.2 \mathrm{~s}$; power 1.7-2. W; spot size $0.1 \mathrm{~cm}$; number of exposures 495). After 1 month, good results were observed in the tested area and the rest of lesions on the lower lip were treated similarly during 5 sessions, with 3 weeks between each argon laser surgery. This allowed to minimized post-operative discomfort such as pain and swelling and to avoid prolonged healing time. During the next 3 years there were no new lesions (Fig. 2b). At age 18 , there was $2 \mathrm{~cm} \times 0.5 \mathrm{~cm}$ regrowth of papillomatosis on the right corner of the mouth 

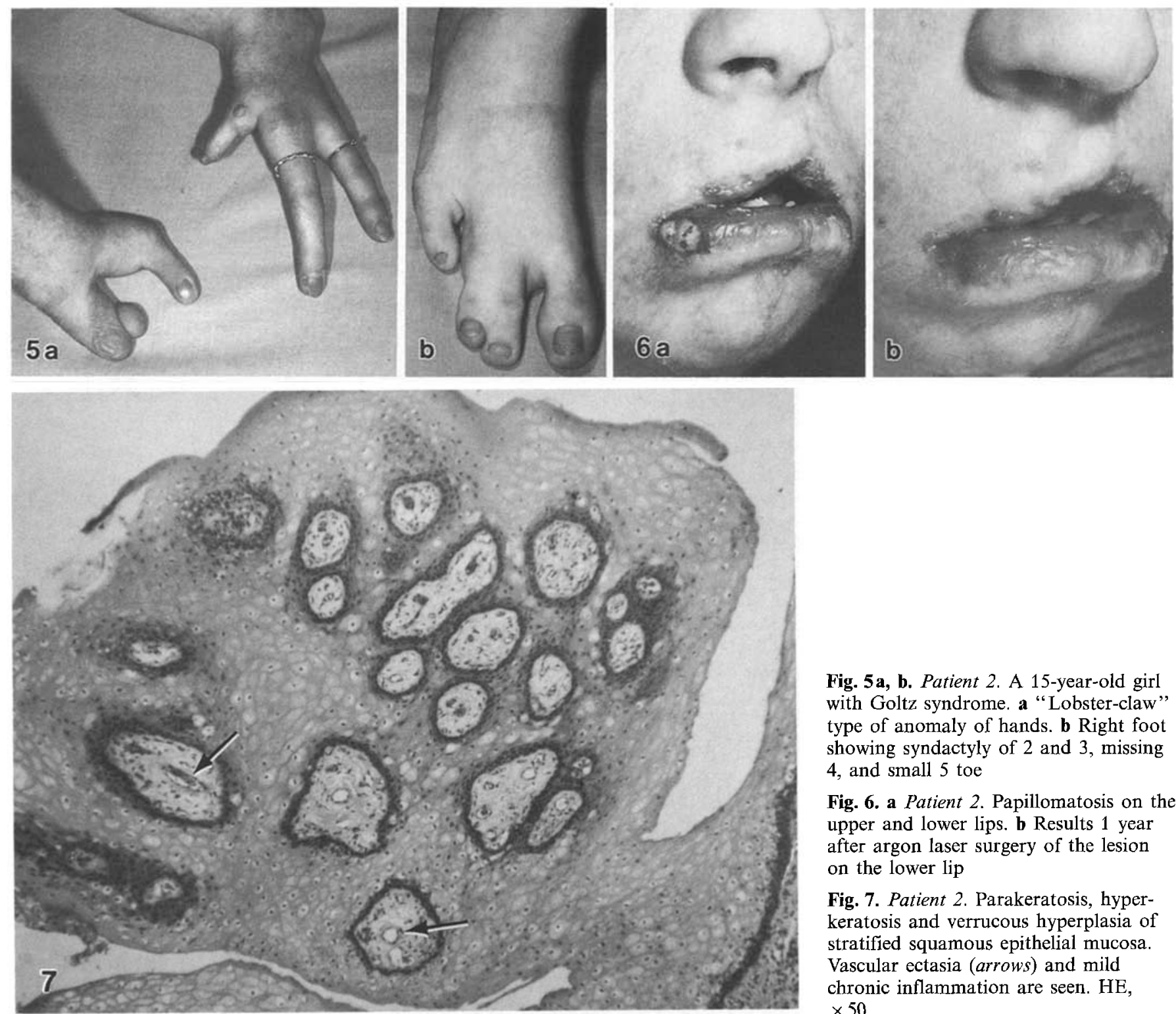

Fig. 5a, b. Patient 2. A 15-year-old girl with Goltz syndrome. a "Lobster-claw" type of anomaly of hands. b Right foot showing syndactyly of 2 and 3 , missing 4 , and small 5 toe

Fig. 6. a Patient 2. Papillomatosis on the upper and lower lips. b Results 1 year after argon laser surgery of the lesion on the lower lip

Fig. 7. Patient 2. Parakeratosis, hyperkeratosis and verrucous hyperplasia of stratified squamous epithelial mucosa. Vascular ectasia (arrows) and mild chronic inflammation are seen. HE, $\times 50$

(Fig. 4a). Retreatment was done, in one session, using the same laser conditions (Fig. 4 b). During the past 4 years there has been no recurrence of the lesions.

\section{Patient 2}

A second patient with the Goltz syndrome was a 15-year-old girl, born with multiple congenital anomalies including lobster-claw type deformities of the hands and right foot and absence of the left foot (Figs. 5a, b). She had a wide cleft at the left side of the face that extended into the corner of the orbit, cleft of the palate and conductive hearing loss of the left ear. Her mother had a severe viral infection during pregnancy. No family members had similar anomalies.

The patient has had multiple reconstructive procedures including open heart surgery for pulmonary valve atresia.

During examination the left leg was missing beyond the midtibia. Her left ear and left eye were disfigured by scars. The nose was twisted and foreshortened. There was a lack of muscle union across the lip and a relative absence of the entire left upper lip from the cleft laterally. Lower lip was redundant and prominent.
Her mouth showed clefting and altered dentition. The mandible was small and hypoplastic. On the body were numerous areas of the skin with the focal dermal hypoplasia. On the right site of the upper and lower lips were slightly verrucous, reddish papillomas, $3 \mathrm{~mm}$ and $1 \mathrm{~cm}$ in diameter respectively (Fig. 6a). Microscopically, parakeratotic hyperkeratosis and verrucous hyperplasia of the stratified squamous epithelial mucosa were seen. Ectasia of blood vessels and mild chronic inflammation in the papillomatous submucosa were also present (Fig. 7).

Following local anesthesia, using $2 \%$ lidocaine without epinephrine, papillomatous lesions on the lower lip were removed during one session using the argon laser with a power density of $255 \mathrm{~W} / \mathrm{cm}^{2}$, i.e., energy fluence $50.9 \mathrm{~J} / \mathrm{cm}^{2}$ (exposure time, $0.2 \mathrm{~s}$; power, $2.0 \mathrm{~W}$; spot size, $0.1 \mathrm{~cm}$; number of exposures 476 ). There was no recurrence of the lesions after one year (Fig. 6b).

\section{Discussion}

EEC syndrome is a very complex congenital disorder. Although its acronym suggests only ectrodactyly, ectodermal dysplasia and clefting of the lip and palate, nu- 
merous other abnormalities associated with this rare autosomal dominant entity are extensive. Ocular involvement in the EEC syndrome includes nasolacrimal anomalies, progressive keratopathy, blepharitis, chronic dacryocystitis, dystrophic keratitis, corneal scarring and neovascularization, absence of meibomian glands, photophobia, epiphora as well as retinal complication [20, $22,30,31,39]$. Conductive hearing loss associated with the EEC syndrome was reported in $13 \%$ of the patients $[23,36]$ and mental retardation in $8 \%$ [23]. Renal anomalies and urinary tract involvement in patients with the EEC syndrome are more frequent than has been previously recognized $[27,38]$, therefore London and colleagues [27] proposed a new name: the EECUT syndrome instead of the EEC syndrome. The classical skin abnormality observed in patients with the EEC syndrome is ectodermal dysplasia, i.e., defective nails, hypotrichosis, hypodontia and heat intolerance in the anhydrotic form [39], but comedone nevus was also reported [26]. Perioral papillomatous lesions, however, were observed in patient \#1 and were never described before in the EEC syndrome. These findings were reported with the Goltz syndrome (focal dermal hypoplasia) rather than the EEC syndrome [3, 29, 35].

There are complexities of the variability of abnormalities that are associated with the EEC syndrome $[1,19]$. On the other hand, although the classical symptoms of the EEC syndrome are usually present they are not obligatory $[18,24,46]$, and an incomplete form of the EEC syndrome may exist $[7,34]$. Also, there is not always full penetrance of the syndrome $[24,40]$ and in some cases it is reduced to $78 \%$ [28].

Abnormalities in the Goltz syndrome are also variable but the skin defects such as atrophic areas with herniations of fat, focal eroded lesions with total absence of the epidermis and dermis, scars, telangiectases, hyperpigmentation and papillomatosis are the most common manifestations of this entity $[3,29,35]$.

Papillomatosis on the mucous membranes of the lips are recalcitrant lesions and not easy to treat without radical intervention. We tried, for the first time, to use the argon laser in pulsed mode for removal of these lesions and to observe its effectiveness. The presence of numerous dilated small blood vessels filled with red blood cells (see Figs. 3 and 7) increases absorption of argon laser energy causing coagulation and carbonization of papillomatous lesions.

The $\mathrm{CO}_{2}$ laser, however, although does not operate in a vessel-specific manner, was also used in oral surgery. Its infrared light $(10,600 \mathrm{~nm})$ is absorbed by water in the tissue and immediately converted into heat, which causes the cellular water to boil, producing a vaporized crater. The $\mathrm{CO}_{2}$ laser in the focused (excisional) mode or defocused (vaporizational) mode has been utilized with good to excellent results in removing such lesions on the lips and oral mucosa as actinic cheilitis $[5,14$, $15,37,41,44,45,47]$, leukoplakia $[4,5,14,17,21$, $25,42]$, oral florid papillomatosis [33], sublingual keratosis [11], cornu cutaneoum [14], mucosal warts [25], benign oral hyperkeratosis and verrucous carcinoma $[10$, 12]. All verrucous lesions on mucous membranes, especially oral "hairy" leukoplakia associated with Aids [32], mucocutaneous Aids-associated Kaposi's sarcoma [2] and oral condyloma planum - a variant of leukoplakia that probably is a prodromal sign of the Aids virus infection in homosexual men [9] should be treated with extreme caution and safety during the laser surgery. Gardner et al. [13] revealed presence of the intact human papillomavirus DNA in the vapor of $\mathrm{CO}_{2}$ laser-treated verrucae and warned about their liberation into the air.

Successful results of treatment of our 2 patients indicate that the argon laser can also be effectively used instead of the $\mathrm{CO}_{2}$ laser in the treatment of verrucous and papillomatous lesions on the mucous membranes. Because the laser energy is not cumulated in tissues it may be used repeatedly for treatment of regrowing lesions.

\section{References}

1. Brautigam B, Bender SW (1987) EEC Syndrom. Mögliche Assoziation mit Alpha-1-Antitrypsinmangel. Dtsch $Z$ Mund Kiefer Gesichtschir 11:309-315

2. Bratzke B, Stadler R, Eichhorn R, Ehlers G, Orfanos CE (1987) Disseminiertes mukokutanes Kaposi-Sarkom bei Aids. Klinische und therapeutische Erfahrungen an 13 Patienten. Hautarzt $38: 286-294$

3. Burgdorf WHC, Dick GF, Soberberg MD et al (1981) Focal dermal hypoplasia in a father and daughter. J Am Acad Dermatol 4:273-277

4. Chiesa F, Sala L, Costa L, Moglia D, Mauri M et al (1986) Excision of oral leukoplakias by $\mathrm{CO}_{2}$ laser on an out-patient basis: a useful procedure for prevention and early detection of oral carcinomas. Tumori $72: 307-312$

5. Cisneros JL, Singla R, Oliveras F, Marti M (1990) Cutaneomucous precancer, treatment using $\mathrm{CO}_{2}$ laser. Med Cut Ibero Lat Am 18:23-29

6. Cockayne EA (1936) Cleft palate, hare lip, dacryocystitis and cleft hand and feet. Biometrika $28: 61$

7. Dieker H, Opitz JM (1969) Associated acral and renal malformations. Birth Defects 3:68-77

8. Eckoldt JG, Martens FH (1804) Ueber eine sehr komplizierte Hasenscharte oder einen sogenannten Wolfsrachen mit einer an demselben Subjeckte befindlichen merkwürdigen Misstaltung der Hände und Füsse. Steinacker, Leipzig

9. Eversole LR, Jacobsen P, Stone CE, Freckleton V (1986) Oral condyloma planus (hairy leukoplakia) among homosexual men: a clinicopathological study of thirty-six cases. Oral Surg Oral Med Oral Pathol 61:249

10. Flynn MB, White M, Tabah RJ (1988) Use of carbon dioxide laser for the treatment of premalignant lesions of the oral mucosa. J Surg Oncol 37:232-234

11. Frame JW (1984) Treatment of sublingual keratosis with the carbon dioxide laser. Br Dent J 156:243-246

12. Frame JW (1985) Removal of oral soft tissue pathology with the $\mathrm{CO}_{2}$ laser. J Oral Maxillofac Surg 43:850-855

13. Garden JM, OBanion MK, Shelnitz LS, Pinski KS, Bakus AD, Reichmann ME, Sundberg JP (1988) Papillomavirus in the vapor of carbon dioxide laser-treated verrucae. JAMA 259:11991202

14. Gáspár L and Szabó G (1990) Manifestation of the advantages and disadvantages of using the $\mathrm{CO}_{2}$ laser in oral surgery. $\mathrm{J}$ Clin Laser Med Surg 8:39-43

15. Goldberg DJ (1989) Laser surgery of the skin. Am Fam Physician 40:109-116

16. Goltz RW, Peterson WC, Gorlin RJ, Ravits HG (1962) Focal dermal hypoplasia. Arch Dermatol 86:708-717 
17. Grossenbacher R (1985) Laserchirurgie in der Oto-Rhino-Laryngologie. Thieme, New York, p 64

18. Gualandri V, Ronzoni MG, Montagnani A et al (1986) Une famille atteinte de EEC-syndrome (ectrodactyly ectodermaldysplasia clefting syndrome: variabilité clinique et conseil génétique. J Fr Ophtalmol 9:855-857

19. Haensch R, Kuster W, Hammerstein W (1985) Ektrodaktylie, ektodermale Dysplasie, Lippen-Kiefer-Gaumenspaltensyndrom (EEC-Syndrom). Kombination mit dem Van der Woude-Syndrom? Dtsch Z Mund Kiefer Gesichtschir 9:225-226

20. Kaiser-Kupfer M (1973) Ectrodactyly ectodermal dysplasia and clefting syndrome. Am J Ophthalmol 76:992-998

21. Kaplan I, Giles S (1984) $\mathrm{CO}_{2}$ laser surgery. Springer, New York

22. Koniszewski G, Mayward M, Henke V (1987) Augenbeteiligung bei ektodermaler Dysplasie. Klin Monatsbl Augenheilkd 190: 519-523

23. Kuster W (1986) Further reports of urinary tract involvement in EEC syndrome. Am J Dis Child 140:411

24. Kuster W, Majewski F, Meinecke P (1985) EEC syndrome without ectrodactyly? Report of 8 cases. Clin Genet 28:130-135

25. Landthaler M, Haina D, Hohenleutner U, Seipp W, Waidelich W, Braun-Falco O (1988) Der $\mathrm{CO}_{2}$-Laser in der Dermatotherapie - Anwendung und Indikation. Hautarzt 39:198-204

26. Leibowitz MR, Jenkins T (1984) A newly recognized feature of ectrodactyly, ectodermal dysplasia, clefting (EEC) syndrome: comedone naevus. Dermatologica 169:80-85

27. London R, Heredia RM, Israel J (1985) Urinary tract involvement in EEC syndrome. Am J Dis Child 139:1191-1193

28. Majewski F, Kuster W (1988) EEC syndrome sine sine? Report of a family with oligosymptomatic EEC syndrome. Clin Genet 33:69-72

29. Mallory SB, Krafchik BR (1989) Goltz syndrome. Pediatr Dermatol 16:251-253

30. Mawhorter LG, Ruttum MS, Koenig SB (1985) Keratopathy in a family with the ectrodactyly-ectodermal dysplasia-clefting syndrome. Ophthalmology 92:1427-1431

31. Mondino BJ, Bath PE, Foos RY et al (1984) Absent meibomian glands in the ectrodactyly, ectodermal dysplasia, cleft lip-palate syndrome. Am J Ophthalmol 97:496-500
32. Nasemann T (1988) Einige neuere Ergebnisse und Entwicklungen in der Dermatovenerologie. Laryngol Rhinol Otol (Stuttg) 67:343-345

33. Persley MS (1984) Carbon dioxide laser treatment of oral florid papillomatosis. J Derm Surg Oncol 10:64-66

34. Predine-Hug F, Le Merrer M, Frezal J (1984) Dysplasie ectodermique et ectrodactylie familiale. Arch Fr Pediatr $41: 49-50$

35. Prentice FM, Mackie RM (1982) A case of focal dermal hypoplasia. Clin Exp Dermatol 7:149-153

36. Robinson GC, Wildervanck LS, Chiang TP (1973) Ectrodactyly, ectodermal dysplasia, and cleft lip-palate syndrome. Its association with conductive hearing loss. J Pedriatr 82:107-109

37. Robinson JK (1989) Actinic cheilitis. A prospective study comparing four treatment methods. Arch Otolaryngol Head Neck Surg 115:848-852

38. Rollnick BR, Hoo JJ (1988) Genitourinary anomalies are a component manifestation in the ectodermal dysplasia ectrodactyly, cleft lip/palate (EEC) syndrome. Am J Med Genet 29:131136

39. Rudiger RA, Haase W, Passarge E (1970) Association of ectrodactyly, ectodermal dysplasia, and cleft lip-palate. The EEC syndrome. Am J Dis Child 120:160-163

40. Smith DW (1982) Recognizable pattern of human malformation, 3rd edn. Saunders, Philadelphia, pp 162-163

41. Stanley RJ, Roenigk RK (1988) Actinic cheilitis : treatment with the carbon dioxide laser. Mayo Clin Proc 63:230-235

42. Strong MS, Jako GJ, Polanyi et al (1973) Laser surgery in the aerodigestive tract. Am J Surg 126:529

43. Walker JC, Clodius L (1963) The syndromes of cleft lip, cleft palate and lobster-claw deformities of hands and feet. Plast Reconstr Surg 32:627-636

44. Whitaker DC (1984) Treatment of actinic cheilitis by $\mathrm{CO}_{2}$ laser. Lasers Surg Med 3:334

45. Whitaker DC (1987) Microscopically proven cure of actinic cheilitis by $\mathrm{CO}_{2}$ laser. Lasers Surg Med 7:520-523

46. Yap HK, Lee BW, Tay JSH et al (1985) Ectrodactyly, ectodermal dysplasia and cleft lip syndrome. J Singapore Paediatr Soc 27:215-217

47. Zelickson BD, Roenigk RK (1990) Actinic cheilitis. Treatment with the carbon dioxide laser. Cancer 65:1307-1311 